\title{
Pengembangan Buku Komik Pokok Bahasan Sistem Peredaran Darah
}

\author{
Nabiela Dini Agathaa, Jekti Prihatin', Erlia Narulita ${ }^{\mathrm{c}}$ 1* $^{*}$ \\ a,b,c Program Studi Pendidikan Biologi FKIP, Universitas Jember, J1. Kalimantan 37, Jember 68121 Indonesia \\ 1 erlia.fkip@unej.ac.id* \\ *korespondensi penulis
}

ABSTRAK

Penelitian ini bertujuan untuk menghasilkan komik yang valid, praktis, dan efektif pada pokok bahasan sistem peredaran darah kelas 8. Penelitian dilakukan dalam tiga tahap yaitu define, desigen, develop. Pengambilan data menggunakan instrumen antara lain lembar validasi, angket keterbacaan, soal pre-test post-test, dan angket respon siswa. Uji coba produk dilakukan dengan uji coba terbatas dan uji coba kelompok besar. Subjek uji coba yaitu 35 siswa kelas 8A SMPN 1 Kalibaru Banyuwangi. Hasil analisis terhadap aspek validitas buku komik mencapai kriteria sangat valid, aspek kepraktisan buku komik memiliki kriteria sangat baik dan menunjukkan bahwa bahan ajar buku komik tergolong praktis, aspek keefektifan buku komik masuk dalam kategori sedang. Bahan ajar buku komik sistem peredaran darah ini memiliki kriteria sangat valid, praktis dan efektif, sehingga dapat diimplementasikan secara luas dalam pembelajaran.

Kata kunci: bahan ajar, buku komik, efektivitas, kepraktisan, validitas

\begin{abstract}
Development of the circulatory system comic book. This research aim to produce comics that valid, practical, and effective on the subject of the circulatory system grade 8 . The research was conducted in three stages ie define, desigen, develop. The data were collected by using instrument include validation sheet, questionnaire, pre-test and post-test, and student response questionnaire. Product trials were conducted with limited trials and large group trials. The subjects were 35 students of grade 8A SMPN 1 Kalibaru Banyuwangi. The result of the analysis on the comic book validity aspect reached the criterion very valid, the practicality aspect has very good criteria and practical, the effectiveness aspect was in the medium category. The material of this circulation comic book has very valid criteria, practical and effective, so it can be implemented widely in learning.
\end{abstract}

Keyword: comic book, effectiveness, practicality, teaching materials, validity

Copyright (C) 2017 Universitas Ahmad Dahlan. All Right Reserved

\section{Pendahuluan}

Salah satu pokok bahasan pada materi IPA kelas 8 yaitu sistem peredaran darah pada manusia. Menurut (Alfaris, 2015), pokok bahasan ini merupakan salah satu pokok bahasan yang tergolong kompleks, abstrak, memiliki cakupan yang luas serta butuh banyak hapalan. Hasil angket yang diberikan kepada 56 siswa dari SMPN 1 Kalibaru, SMPN 2 Kalibaru dan MTsN Kalibaru Banyuwangi menunjukkan bahwa sebanyak $71,42 \%$ siswa menyatakan bahwa siswa belum memahami materi sistem peredaran darah pada buku yang dimiliki. Kurangnya tingkat pemahaman siswa mengenai materi sistem peredaran darah dikarenakan adanya sikap yang kurang aktif dari siswa yang menjadi faktor rendahnya tingkat pemahaman siswa dan berdampak pada hasil belajar siswa.

Selama mengikuti pembelajaran IPA, siswa dituntut untuk memiliki sikap aktif yang bisa dimulai dengan banyak membaca dan nantinya akan berdampak pada hasil belajar siswa (Pamuji, 2014). Hasil survei UNESCO menunjukkan bahwa minat baca masyarakat Indonesia baru 0,001\%. Hal tersebut berarti dalam seribu masyarakat hanya terdapat satu masyarakat yang memiliki minat baca. Minat baca masyarakat Indonesia masih sangat rendah (Khoiruddin, Taulabi, \& Imron, 2016), sehingga diperlukan penumbuhan minat baca khususnya di kalangan siswa.

Usaha peningkatan minat baca di kalangan siswa telah dilakukan melalui pencanangan gerakan literasi sekolah (GLS) oleh Kementerian Pendidikan dan Kebudayaan melalui Peraturan Menteri No. 23 Tahun 2013. Salah satu upaya yang digunakan untuk menumbuhkan mendukung GLS dan meningkatkan minat baca yaitu dengan menggunakan buku yang menarik dan sesuai dengan usia siswa (Pamuji, 2014). Akan tetapi, buku pelajaran yang banyak digunakan atau dimiliki oleh siswa merupakan buku yang verbalistik sehingga membuat siswa menjadi jenuh karena kalimat di dalam buku disajikan secara kaku serta kurang komunikatif. Hal ini tentunya akan berdampak pada menurunnya minat baca siswa sehingga dibutuhkan penggunaan buku yang mampu meningkatkan minat baca siswa, salah satunya yaitu buku komik yang mempunyai ilustrasi dan gambar yang menarik. 
Komik merupakan media yang memiliki ilustrasi berwarna, alur cerita dengan perwatakan orang yang realistis sehingga menarik semua anak dari berbagai tingkat usia. Komik dapat dipergunakan oleh guru dalam usaha membangkitkan minat siswa dalam membaca (Lubis \& Hasanah, 2016). Digunakannya komik dalam pembelajaran menjadi suatu harapan bagi guru sehingga dapat pembimbing dan memotivasi siswa untuk lebih menyenangi keahlian dalam membaca.

Hasil angket yang diberikan pada SMPN 1 Kalibaru, SMPN 2 Kalibaru dan MTsN Kalibaru Banyuwangi menunjukkan bahwa 98\% siswa dan $100 \%$ guru IPA setuju apabila akan dikembangkan bahan ajar berupa buku komik yang berisi materi sistem peredaran darah. Oleh karena itu, permasalahan di atas dapat diatasi dengan melakukan penelitian pengembangan yang bertujuan untuk menghasilkan suatu bahan ajar berupa buku komik yang valid, efektif, dan praktis yang dapat digunakan oleh siswa.

\section{Metode Penelitian}

Penelitian ini menggunakan penelitian pengembangan model 4D, dengan pembatasan pada tiga tahapan yaitu define (pendefinisian), design (perencanaan), dan develop (pengembangan). Tahap penyebaran tidak dilakukan karena tujuan penelitian ini sudah dapat diperoleh pada tahap develop (pengembangan), yaitu mengembangkan bahan ajar yang valid, efektif dan praktis (Bito dalam Mohamad, 2015). Uji coba produk dilakukan di SMPN 1 Kalibaru Banyuwangi. Kriteria komik yang dikembangkan adalah komik sistem peredaran darah untuk kelas 8 yang minimal memenuhi kriteria baik dari aspek kevalidan dan aspek kepraktisan, serta efektif untuk meningkatkan kognitif siswa dengan nilai indeks gain sedang.

Validitas buku komik diukur menggunakan hasil validasi oleh validator dan hasil pengisian angket keterbacaan oleh 9 siswa kelas 8A SMPN 1 Kalibaru Banyuwangi. Kepraktisan buku komik diukur menggunakan angket respon siswa yang disebarkan pada 35 siswa kelas 8A SMPN 1 Kalibaru Banyuwangi. Efektivitas buku komik diukur dengan menggunakan hasil belajar siswa. Hasil perhitungan yang telah diperoleh selanjutnya diubah menjadi data kuantitatif untuk kemudian dikualitatifkan sebagaimana tabel 1.

Tabel I. Kriteria kevalidan dan kepraktisan buku komik

\begin{tabular}{cc}
\hline Nilai & Kualifikasi \\
\hline $81,25 \leq x \leq 100$ & Sangat baik \\
$62,5 \leq x<81,25$ & Baik \\
$43,75 \leq x<62,5$ & Cukup Baik \\
$25 \leq x<43,75$ & Kurang Baik \\
\hline
\end{tabular}

Adanya peningkatan hasil tes kognitif siswa dianalisis dengan menggunakan rumus indeks gain:

$$
N(\text { gain })=\frac{O_{2}-O_{1}}{\text { skor maksimal }-O_{1}}
$$

Keterangan :

$\mathrm{O}_{1}=$ hasil pengukuran post-test

$\mathrm{O}_{2}=$ hasil pengukuran pre-test (Muhammad, 2016).

Adapun kriteria perolehan indeks gain dapat dilihat pada Tabel 2.

Tabel 2. Kriteria perolehan indeks gain

\begin{tabular}{cc}
\hline $\mathbf{N}($ gain $)$ & Keterangan \\
\hline $\mathrm{g}>0,70$ & Tinggi \\
$0,30 \leq \mathrm{g} \leq 0,70$ & Sedang \\
$\mathrm{g}<0,30$ & Rendah \\
\hline
\end{tabular}

\section{Hasil dan Pembahasan}

Define: pada tahapan ini diperoleh data berupa syarat-syarat yang diperlukan dalam pembelajaran, melalui kegiatan analisis awal akhir, analisis siswa, analisis konsep, analisis tugas dan spesifikasi tujuan pembelajaran. Berdasarkan analisis awal akhir dapat diketahui bahwa sebanyak 55,35\% siswa menggunakan LKS dalam proses pembelajaran IPA dan sebanyak 44,64\% siswa menggunakan buku paket dalam proses pembelajaran IPA. Selain itu, dari analisis dapat diketahui tingkat pemahaman siswa terhadap materi sistem peredaran darah yang disajikan dalam buku yang digunakan, hasilnya hanya $28,58 \%$ siswa yang mampu memahami sedangkan sebanyak 71,42\% siswa tidak mampu memahami materi sistem peredaran darah yang disajikan dalam buku siswa.

Berdasarkan analisis konsep dan tugas dapat diketahui bahwa materi sistem peredaran darah masuk pada kompetensi dasar 3.7. Kompetensi tersebut yaitu menganalisis sistem peredaran darah pada manusia dan memahami gangguan pada sistem peredaran darah, serta upaya menjaga kesehatan sistem peredaran darah.

Berdasarkan spesifikasi tujuan pembelajaran dapat diketahui bahwa ada beberapa tujuan pembelajaran yang hendak dicapai. Tujuan tersebut yaitu: 1) siswa mampu menyebutkan dan menjelaskan komponen darah; 2) siswa mampu menyebutkan dan menjelaskan organ peredaran darah; 3) siswa mampu menjelaskan jenis dan proses peredaran darah pada manusial; dan 4) siswa mengetahui berbagai penyakit pada sistem peredaran darah manusia.

Pada tahap design dihasilkan rancangan awal produk yang siap untuk divalidasi oleh validator. Rncangan awal ini dibuat melalui kegiatan penyusunan tes, pemilihan media, pemilihan format, dan rancangan awal. Tes yang digunakan berupa pretest dan post-test menggunakan 5 soal esai yang 
sama. Media dan format yang digunakan yaitu berupa buku komik.

Pada tahap develop rancangan awal produk pada tahap design diujicobakan. Tahapan ini terdiri dari dua kegiatan, yaitu expert appraisal atau tahapan penilaian terhadap buku komik, serta developmental testing atau kegiatan uji coba produk di lapangan yang sesungguhnya. Uji validasi ini dilakukan oleh para ahli (Istikomayanti, Suwono, \& Irawati, 2016). Menurut (Septiani, 2013), kegiatan validasi dapat dilakukan oleh beberapa ahli yang sudah berpengalaman guna menilai kelebihan dan kelemahan produk yang telah dihasilkan. Hasil penilaian dari validator dijadikan sebagai kontrol mutu dari bahan ajar yang telah dikembangkan (Lestari, 2013). Penilaian validator terhadap rancangan buku komik menujukkan hasil sangat valid dengan nilai seperti pada gambar 1 .

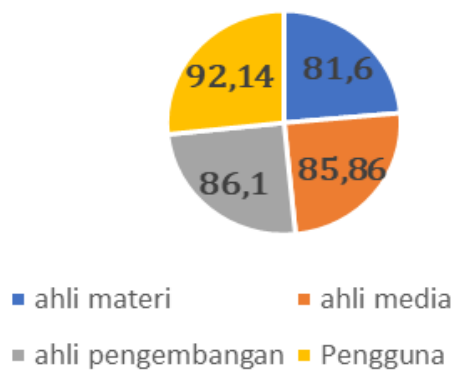

Gambar I. Hasil analisis validasi buku komik oleh ahli

Rancangan buku komik meskipun sudah memenuhi kriteria sangat valid, namun tetap memperoleh kritik, saran dan komentar dari validator. Catatan yang diberikan oleh ahli materi hanya pada aspek kemutakhiran pustaka, karena pada umumnya komik tidak mempunyai pustaka dan keseluruhan isi merupakan pemikiran atau kreativitas dari komikus. Selain itu, ahli materi memberikan saran untuk memperbaiki judul buku komik dan adanya kesalahan konsep pada pengertian peredaran darah besar. Berdasarkan catatan ahli materi dilakukan perbaikan pada buku komik.

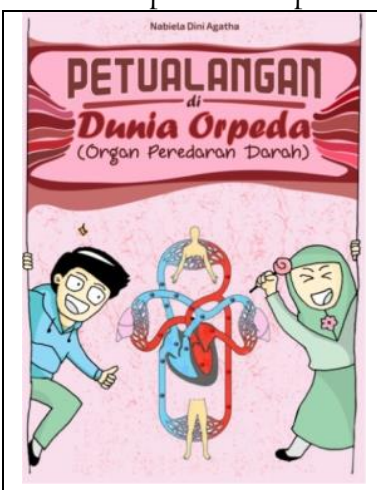

(a)

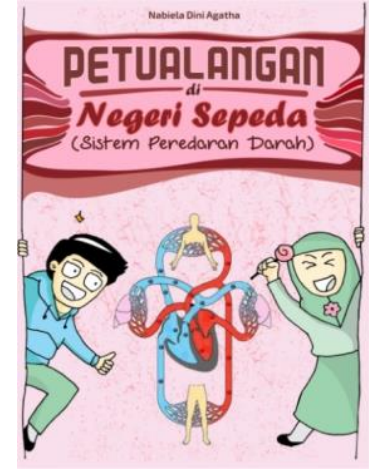

(b)
Gambar 2. Cover buku komik (a) rancangan awal dan (b) hasil revisi
Ahli media memberikan catatan pada aspek ukuran buku komik yang dinilai kurang pas untuk kriteria komik, dimana peneliti membuat buku komik dengan ukuran A5 dengan dasar pertimbangan pada ukuran tersebut materi dapat disajikan dengan jelas. Apabila buku komik disajikan dalam ukuran yang lebih kecil, dikhawatirkan gambar pendukung dari materi sistem peredaran darah tidak dapat disajikan dengan jelas dan akan berpengaruh pada respon dan hasil belajar siswa. Selain itu, ahli media memberikan saran penambahan deskripsi latar belakang masing-masing tokoh, penggantian istilah daftar isi agar lebih sesuai dengan konsep buku komik, dan pemberian halaman. Berdasarkan masukan dari ahli media, rancangan buku komik disesuaikan dengan mempertimbangkan kefektifan desain dan konten dalam komik.

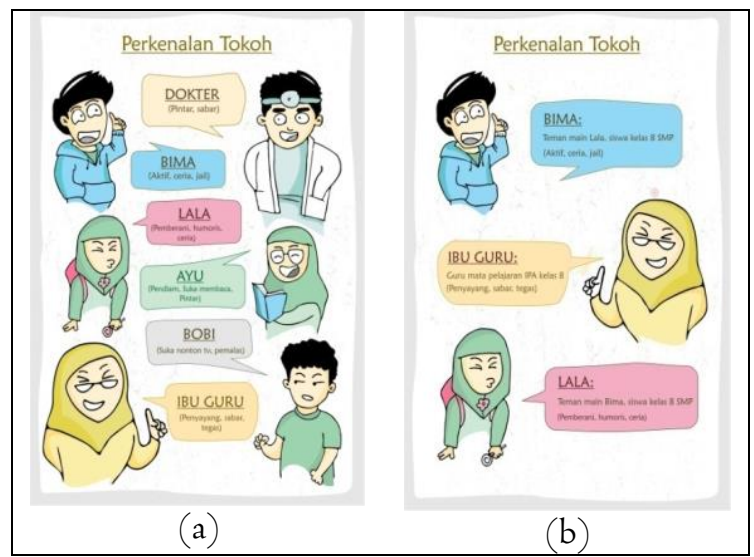

Gambar 3. Pengenalan tokoh (a) rancangan awal dan (b) revisi dengan penambahan deskripsi latar belakang masing-masing tokoh

Ahli pengembangan memberikan catatan masih ditemukan beberapa kesalahan penulisan dalam buku komik. Selain itu terdapat candaan yang dinilai kurang tepat dan perlu penambahan gambar pendukung.

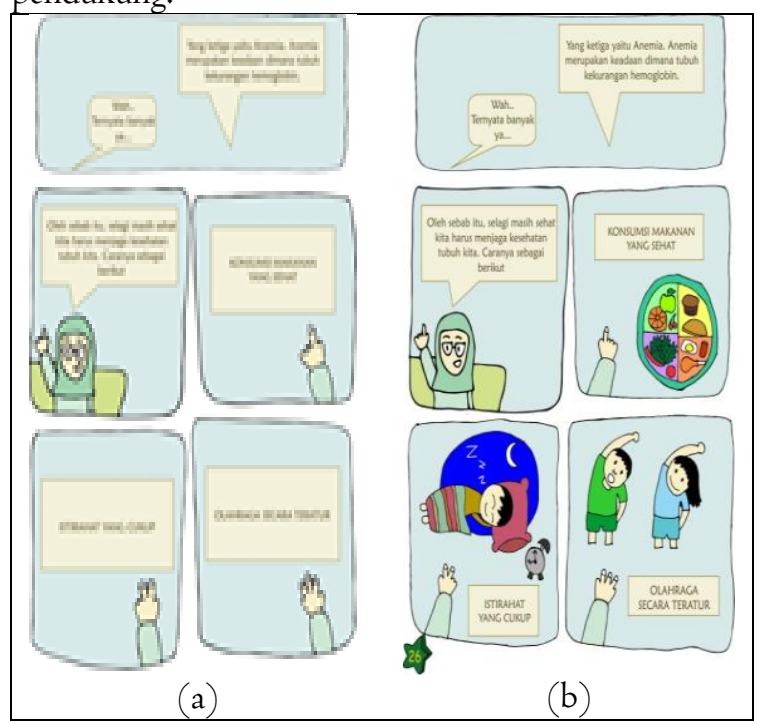

Gambar 4. Gambar pendukung yang telah ditambahkan: (a) rancangan awal, (b) hasil revisi 
Revisi terhadap rancangan dilakukan untuk meningkatkan kualitas buku komik yang telah dikembangkan, sesuai dengan komentar dan saran dari validator. Revisi dilakukan untuk menghasilkan produk yang benar-benar valid dan layak untuk digunakan (Astutik, 2012). Rancangan awal (draft 1) yang telah divalidasi dan direvisi menghasilkan produk (draft II) yang selanjutnya dilakukan developmental testing (uji coba). Kegiatan uji coba pertama dilakukan secara terbatas dengan melibatkan 9 siswa kelas 8A SMPN 1 Kalibaru Banyuwangi. Ujii coba terbatas dilakukan untuk melihat aspek keterbacaan. Hasil analisis aspek keterbacaan tersaji pada tabel 3.

Tabel 3. Hasil analisis uji keterbacaan buku komik

\begin{tabular}{lcc}
\hline \multicolumn{1}{c}{ Aspek } & Rata-rata(\%) & Kategori \\
\hline Keterbacaan buku komik & $94,44 \%$ & Sangat baik \\
$\begin{array}{l}\text { Komponen kegiatan siswa } \\
\text { Keterbacaan kegiatan } \\
\text { siswa }\end{array}$ & 86,1 & Sangat baik \\
$\begin{array}{l}\text { Kemenarikan penyajian } \\
\text { permasalahan }\end{array}$ & 77,77 & Baik \\
\begin{tabular}{l} 
Mendorong bersikap aktif \\
\multicolumn{1}{c}{ Rata-rata }
\end{tabular} & 77,77 & Baik \\
& 88,88 & Sangat baik \\
\end{tabular}

Tabel 3 menunjukkan bahwa uji keterbacaan memperoleh rerata penilaian pada kategori sangat baik. Melihat hasil ini dapat disampaikan bahwa rancangan produk siap untuk digunakan di lapangan dalam uji coba selanjutnya. Meskipun demikian masih ditemukan adanya kesulitan yang dialami oleh siswa terkait pada keterbacaan komik. Kesulitan terletak pada penggunaan ukuran font pada buku komik, dimana terdapat beberapa percakapan dalam buku komik yang menggunakan ukuran font terlalu kecil sehingga siswa mengalami kesulitan dalam membaca percakapan tersebut. Oleh karena itu, dilakukan perbaikan pada ukuran font demi meningkatkan aspek keterbacaan.

Hasil validasi dari validator dan uji keterbacaan buku komik ini merupakan parameter pengukuran validitas buku komik. Berdasarkan hasil yang telah diperoleh dapat diketahui bahwa buku komik masuk dalam kategori sangat valid sehingga buku komik siap untuk dimanfaatkan pada lapangan yang sesungguhnya.

Pada aspek kepraktisan buku komik diukur menggunakan angket respon siswa. Pembagian angket respon siswa dilakukan setelah siswa membaca dan memahami isi dari buku komik. Kepraktisan bahan ajar berkaitan dengan kemudahan penggunaan bahan ajar yang telah dikembangkan (Septiani, 2013).

Angket respon siswa diisi oleh 35 siswa kelas 8A SMPN 1 Kalibaru. Angket respon siswa berisi 3 indikator penilaian yaitu ketertarikan, materi, dan bahasa. Hasil analisis kepraktisan (tabel 4 menunjukkan buku komik dalam kategori sangat baik, sehingga hal ini mengindikasikan buku komik yang dikembangkan dinilai praktis dan dapat digunakan tanpa adanya revisi.

Indikator ketertarikan meliputi: 1) tampilan buku komik ini menarik; 2) buku komik ini membuat saya lebih bersemangat dalam membaca; 3 ) buku komik membuat belajar IPA tidak membosankan; 4) buku komik mendukung dalam menguasai materi sistem peredaran darah; 5) gambar dan alur cerita dapat memberikan motivasi untuk mempelajari materi. Setelah dilakukan analisis dapat diketahui bahwa respon siswa terhadap masing masing pertanyaan sangat baik. Hal ini didukung dengan pernyataan Lubis (2016), bahwa penggunaan komik dalam kegiatan pembelajaran dapat menciptakan minat belajar dari siswa.

Tabel 4. Hasil analisis respon siswa terhadap buku komik

\begin{tabular}{ccccc}
\hline $\begin{array}{c}\text { Item } \\
\text { no }\end{array}$ & $\begin{array}{c}\text { Skor } \\
\text { yang } \\
\text { diperoleh }\end{array}$ & $\begin{array}{c}\text { Skor } \\
\text { maks }\end{array}$ & Persentase & Interpretasi \\
\hline 1 & 114 & 144 & 79,16 & Baik \\
2 & 118 & 144 & 81,94 & Sangat baik \\
3 & 119 & 144 & 82,63 & Sangat baik \\
4 & 118 & 144 & 81,94 & Sangat baik \\
5 & 115 & 144 & 79,86 & Baik \\
6 & 124 & 144 & 86,11 & Sangat baik \\
7 & 116 & 144 & 80,55 & Baik \\
8 & 119 & 144 & 82,63 & Sangat baik \\
9 & 121 & 144 & 84,02 & Sangat baik \\
10 & 120 & 144 & 83,33 & Sangat baik \\
Rata & 118 & 144 & 81,94 & Sangat baik \\
-rata & & & & \\
\hline
\end{tabular}

Pertanyaan pada item nomor 6 hingga 8 dalam indikator materi yaitu, materi yang disajikan dalam buku komik ini mudah saya pahami; penyampaian materi dalam buku komik ini berkaitan dengan kehidupan sehari-hari; serta buku komik ini memuat tes evaluasi yang dapat menguji seberapa jauh pemahaman saya mengenai materi sistem peredaran darah.

Setelah dilakukan analisis dapat diketahui bahwa respon siswa terhadap masing-masing pertanyaan sangat baik. Hal ini diperkuat dengan pernyataan Ariastutik (2016), bahwa penggunaan komik dalam proses pembelajaran dapat memberikan pemahaman yang mudah pada siswa tetang alur kejadian yang sedang dibahas dalam materi karena adanya alur cerita.

Indikator bahasa disajikan pada pertanyaan pada item nomor 9 dan 10 yaitu, bahasa yang digunakan dalam buku komik ini mudah untuk dipahami, huruf yang digunakan dalam buku komik ini sederhana dan mudah untuk dibaca. Hal ini sesuai dengan pernyataan (Pinasti, Fianto, \& 
Hidayat, 2015), bahwa penggunaan teks atau bahasa dalam buku komik dengan bahasa sehari-hari yang bersifat semi formal dan non-formal, bertujuan supaya pesan atau cerita yang disampaikan lebih mudah untuk diingat oleh target yang diinginkan.

Keefektivan buku komik diukur menggunakan hasil belajar siswa. Dalam hal ini dilakukan kegiatan uji coba kelompok besar dengan subjek penelitian sebanyak 35 siswa kelas 8A SMPN 1 Kalibaru Banyuwangi. Pelaksanaan uji coba kelompok besar, peneliti bertindak sebagai guru dan melaksanakan pembelajaran sesuai dengan RPP yang telah disiapkan. Pelaksanaan pembelajaran diawali dengan kegiatan pre-test dan diakhiri dengan kegiatan posttest. Berdasarkan hasil analisis diketahui adanya peningkatan hasil belajar sebagaimana tersaji pada Tabel 5.

Tabel 5. Hasil analisis pre-test dan post-test

\begin{tabular}{|c|c|c|c|c|}
\hline $\begin{array}{c}\text { Rata- } \\
\text { rata } \\
\text { pre- } \\
\text { test }\end{array}$ & $\begin{array}{l}\text { Rata- } \\
\text { rata } \\
\text { post- } \\
\text { test }\end{array}$ & $\begin{array}{l}\text { Rata- } \\
\text { rata } \\
\text { selisih }\end{array}$ & $\begin{array}{c}\text { Rata-rata } \\
\text { normalized } \\
\text { gain }\end{array}$ & kriteria \\
\hline 37,57 & 78,71 & 41,14 & 0,66 & Sedang \\
\hline
\end{tabular}

Hasil pada tabel 5 menunjukkan bahwa ratarata normalized gain sebesar 0,6 dan peningkatan yang terjadi termasuk dalam kategori sedang. Maka dapat diambil keputusan bahwa buku komik tergolong efektif karena dapat meningkatkan hasil belajar siswa.

Peningkatan hasil belajar dikarenakan adanya peningkatan minat baca dari siswa. Minat baca siswa yang tinggi akan berdampak pada tingginya hasil belajar. Selama melaksanakan pembelajaran, digunakan bahan ajar berupa buku komik (Nurlatipah, Juanda, \& Maryuningsih, 2015). Penggunaan buku komik yang memiliki gambar dan alur cerita merupakan faktor meningkatnya minat baca siswa. Hal ini dikarenakan materi yang ada dalam buku komik disajikan dalam bentuk cerita bergambar sehingga materi mudah dimengerti.

Salah satu bacaan yang diminati siswa saat ini adalah komik. Sebagian besar siswa lebih suka membaca komik dibandingkan dengan buku-buku pelajaran. Komik merupakan media cetak yang memadukan teks dengan gambar berdasarkan suatu alur cerita (Rahayu, Sutikno, \& Masturi, 2015). Komik sangat efisien dalam menyampaikan materi sains (Tatalovic, 2009) dan efektif untuk digunakan dalam pembelajaran karena mendorong siswa untuk tertarik membacanya tanpa rasa bosan dengan adanya pesan bergambar yang lebih mudah diingat sehingga materi dapat tersampaikan (Nugraha, 2017).

Berdasarkan hasil yang telah diperoleh, dapat dikatakan bahwa buku komik yang telah dikembangkan termasuk efektif karena telah mampu memberikan peningkatan terhadap hasil belajar siswa. Hasil penelitian ini konsisten dengan hasil penelitian yang dilakukan oleh Lin \& Lin (2016) bahwa penggunaan komik sains mampu meningkatkan hasil belajar dibandingkan buku teks. Kurniawati, Wahyuni, \& Putra (2017) juga memperoleh hasil adanya peningkatan hasil belajar kognitif, afektif dan psikomotor dengan penggunaan komik dalam integrasi pelajaran IPA dengan local wisdom (kearifan lokal).

\section{Simpulan}

Berdasarkan hasil dan pembahasan yang telah diuraikan, maka dapat diperoleh kesimpulan bahwa: 1) Rata-rata hasil uji validasi buku komik oleh validator ahli sebesar 84,52 dan oleh validator pengguna sebesar 92,14, artinya buku komik yang dikembangkan telah mencapai kriteria sangat valid. Rata-rata persentase uji keterbacaan pada 9 siswa $8 \mathrm{~A}$ di SMPN 1 Kalibaru Banyuwangi sebesar 84,99 dan diinterpretasikan dalam kategori sangat baik. 2) Hasil uji kepraktisan buku komik sebesar 81,94\% dan diinterpretasikan dalam kategori sangat baik. Hasil tersebut menunjukkan bahwa bahan ajar tergolong praktis. 3) Hasil uji keefektifan buku komik memeroleh rata-rata normalized gain sebesar 0,6 dan peningkatan yang terjadi masuk dalam kategori sedang. Maka dapat diambil keputusan bahwa buku komik tergolong efektif karena dapat meningkatkan hasil belajar siswa.

\section{Daftar Pustaka}

Alfaris, S. (2015). Efektivitas prestasi belajar (kognitif c1-c3) dari penerapan model pembelajaran kooperatif tipe jigsaw dengan tipe think pair share (TPS) siswa kelas VII materi sistem peredaran darah manusia. JUPEMASI-PBIO, 1(2), 269-272.

Ariastutik, E., Kusmayadi, T. A., \& Sujadi, I. (2016). Pengembangan modul matematika berilustrasi komik pada materi skala dan perbandingan kelas VII SMP/MTs. Journal of Mathematics and Mathematics Education, 6(2), 131-141.

Astutik, R. D. (2012). Pengembangan media pembelajaran membaca aksara jawa berbasis macromedia flash untuk siswa kelas VII SMP. Universitas Negeri Malang, Malang.

Istikomayanti, Y., Suwono, H., \& Irawati, M. H. (2016). Pembelajaran eksperiensial group investigation (GI) sebagai upaya 
mengembangkan kemampuan literasi lingkungan siswa kelas IV MI. JPBI: Jurnal Pendidikan Biologi Indonesia, 2(1), 57-71. https://doi.org/10.22219/JPBI.V2I1.3372. G3961

Khoiruddin, M. A., Taulabi, I., \& Imron, A. (2016). Menumbuhkan minat baca sejak dini di taman baca masyarakat. Journal An-nafs, 1(2), 291-319.

Kurniawati, A. A., Wahyuni, S., \& Putra, P. D. A. (2017). Utilizing of comic and jember's local wisdom as integrated science learning materials. International Journal of Social Science and Humanity, 71 ), 47-50. https://doi.org/10.18178/ijssh.2017.7.1.793

Lestari, I. (2013). Pengembangan bahan ajar berbasis kompetensi (sesuai dengan Kurikulum Tingkat Satuan Pendidikan). Padang: Akademia Permata.

Lin, S.-F., \& Lin, H. (2016). Learning nanotechnology with texts and comics: the impacts on students of different achievement levels. International Journal of Science Education, 38(8), 1373-1391. https://doi.org/10.1080/09500693.2016.1 191089

Lubis, H. Z., \& Hasanah, R. (2016). Penggunaan media komik melalui metode learning starts with a question dalam meningkatkan hasil belajar siswa. In Seminar Nasional Pendidikan Berkemajuan dan Menggembirakan (The Progressive \& Fun Education Seminar) (hal. 589-593). Sumatera Utara: Muhammadiyah University Press.

Mohamad, S. R. (2015). Pengembangan perangkat pembelajaran matematika model penemuan terbimbing di SMP kelas VIII pada materi kubus dan balok. Universitas Negeri Gorontalo, Gorontalo.

Muhammad, A. R. (2016). Peranan metode brainstorming terhadap kemampuan berpikir divergen mahasiswa politeknik negeri media kreatif makassar. Kreator, $3(1), 38-53$

Nugraha, A. (2017). Pengembangan media komik motivasi berprestasi sebagai layanan bimbingan pribadi bagi siswa SMP
Muhammadiyah 1 Godean. Jurnal Riset Mahasiswa Bimbingan Dan Konseling, 3(6), 465-473. Diambil dari http://journal.student.uny.ac.id/ojs/ojs/in dex.php/fipbk

Nurlatipah, N., Juanda, A., \& Maryuningsih, Y. (2015). Pengembangan media pembelajaran komik sains yang disertai foto untuk meningkatkan hasil belajar siswa kelas VII SMPN 2 sumber pada pokok bahasan ekosistem. Scientiae Educatia: Jurnal Pendidikan Sains, 4(2). Diambil dari http://syekhnurjatiac.id/jurnal/index.php/sced ucatia

Pamuji, M. B. (2014). Pengembangan komik sebagai media pembelajaran biologi pada materi sistem saraf manusia untuk SMP/MTs kelas IX semester ganjil. Yogyakarta.

Pinasti, R. D., Fianto, A. Y. A., \& Hidayat, W. (2015). Penciptaan buku komik sebagai upaya pengenalan permainan tradisional kepada remaja. Jurnal ArtNouveau, 4(1), 155-162. Diambil dari http://jurnal.stikom.edu/index.php/ArtN ouveau

Rahayu, A., Sutikno, S., \& Masturi, M. (2015). Pengembangan media pembelajaran hukum Newton menggunakan fotonovela berbasis kearifan lokal. In Prosiding Seminar Nasional Fisika (hal. 33-37). Jakarta: Universitas Negeri Jakarta.

Septiani, A. (2013). Pengembangan bahan ajar cd interaktif materi suhu dan kalor berbentuk powerpoint materi suhu dan kalor untuk pembelajaran fisika kelas $\mathrm{x}$ SMA. PILLAR OF PHYSICS EDUCATION, 2(1), 49-56. http://dx.doi.org/10.24036/pend.\%20fisika.v $2 \mathrm{i} 1.729$

Tatalovic, M. (2009). Science comics as tools for science education and communication: a brief, exploratory study. Journal of Science Communication, 8(4), 1-17. 